\begin{tabular}{ll}
\hline \hline MINING AND METALLURGY INSTITUTE BOR & ISSN: 2334-8836 \\
& UDK: 622 \\
\hline \hline
\end{tabular}

\title{
IMPACT OF THE FLOTATION TAILING DUMPS ON THE LIVING ENVIRONMENT OF BOR AND PROTECTIVE MEASURES ${ }^{* *}$
}

\begin{abstract}
In the southeastern Serbia, in the area of the municipality Bor, there are three flotation tailing dumps: FTD Bor, FTD RTH (the ore body H) and FTD Veliki Krivelj. The Flotation Tailing Dump Bor is abandoned, partly reclamated. The other two are active flotation tailing dumps. All three flotation tailing dumps are serious polluters of air, water and soil. The affected zones by dust from these tailing dumps threat large areas in a direction of dominant wind from the northwest direction. The affected areas by the impact zone of dust from: the Bor Flotation Tailing Dump amount to 18,361,074 $\mathrm{m}^{2}$, flotation tailing dump of the ore body H, 3,713,408 $\mathrm{m}^{2}$ and Flotation Tailings Dump Veliki Krivelj, $16,077,805 \mathrm{~m}^{2}$. The most effective measure against dust rising from dry areas by the wind is the use of reclamation with the phases of technical, agrotechnical and biological reclamation.

Keywords: flotation tailing dumps, environmental protection, accidents, flood wave, affected zone
\end{abstract}

\section{INTRODUCTION}

Preparation of the low grade copper ore in the Flotation Plant Bor and Flotation Plant Veliki Pine Krivelj and concentrations of useful components in the form of copper concentrate provides large amounts of flotation tailings, which requires occupation of large areas for their storage (disposal). Thereby, concentrate and tailings are obtained in the mixture with water in a form of pulp. Concentrate, as useful component, is dewatered and stored in bins in the plant for further processing in the Copper Smelter Bor, while tailings is transported to the disposal place predominantly by hydraulic plastic pipes (FTD RTH) and gravity using the concrete channels (FTD V.Krivelj).
Various forms of construction the flotation tailing dumps were used for the flotation tailing dumps Bor, RTH and Veliki Krivelj.

The oldest Flotation Tailing Dump Bor was initially built as a valley type in the Bor stream, then the combined valley and plain type of construction were used for upgrading the tailing dump.

The Flotation Tailing Dump RTH was originally built as a deep type of tailing dump in the excavated area of the open pit $\mathrm{RTH}$, and then the radial method was used for upgrading, nowadays the outgoing method. The Flotation Tailing Dump Veliki Krivelj is the valley type, and dams were built by ingoing method, while the upgrai-

\footnotetext{
* Mining and Metallurgy Institute Bor, 19210 Bor, Serbia

** This work is the result of Project No. 33021 "Research and Monitoring the Changes of Stress-strain State in the Rock Massif "in-situ" Around the Underground Rooms with Development a Model With a Special Review to the Tunnel of the Krivelj River and Jama Bor", funded by the Ministry of Education, Science and Technological Development of the Republic of Serbia
} 
ding is done using the outgoing method. For disposal of flotation tailings, resulting in the processing of ore, the space obtained by damming the Veliki Krivelj river valley is used (1). Tailings was delayed by in-depth type without separating the solid from liquid phase, while in the partitioned areas with dams and peripheral dikes, the cycloning of tailings and separate disposal are done. Only hydrocyclone overflow is deposited into the accumulation area, and the hydrocyclone sand on dams, which also serves as the material for construction of dams and peripheral embankments to the designed level. In order to realize the new extension of flotation tailing dump, it is necessary to previously build the new facilities for deviation the Krivelj River, located in the zone of flotation tailings (2). In this way, the space will be provided for permanent disposal of flotation tailings. (2)

Because of the reliability of service and safe exploitation of predicted space of flotation tailings in order to protect the environment, initially after start the construction of tailing dump with artificial barriers of dams and dikes, the followings were built:

- Basic (starting or initial) dam of solid material (soil, sand or crushed stone) which is the support and filter base,

- Drainage system in the basement of starting dam with collector for acceptance the inflow water and dewatering the dam around the contours of the landfill,

- System for hydro transport, slime cycloning,construction and filling of the dam and peripheral dyke of the flotation tailing dump and disposal of fine slime and water into sedimentary lake,

- System for evacuation of clarified water in the flotation process,

- System for acceptance the inflow and overflow water and their return into sedimentary lake or reuse. Therefore, their proper sizing, design and solid construction are very important.
Disposal of tailings into the accumulation space is performed depending on the field morphology around the tailing dump, the position of sedimentary lake, length of beache, and it is aimed to maximum utilization of available space. In pump discharging into accumulation space, it is taken into account, in the operational work, that its jet does not mechanically damage the foot of inside dam slope.

A lake is formed inside the flotation tailing dump in which the sedimentation of slime from pulp and separation of pure water are performed, where the highest point in relation to the dam elevation must be reduced for 3.0 to $5.0 \mathrm{~m}$ depending on the catchment area around the flotation tailing dump. Clarified water from the lake is returned back into the process by pumps floating on a raft in the lake.

Flotation reagents, representing different chemical compounds, are used in the technological process of flotation concentration, including: xanthogenates, alkali metals, dithiophosphates, polyglycols and lime, which is used for $\mathrm{pH}$ value control of technological water. Flotation reagents are absorbed on the surfaces of particles, and a part remains in the water in dissolved and dispersed state. In addition to water, which is transported into the lake from the Flotation Plant with flotation tailings, the lake is also filled with pure water from the precipitation within the basin of flotation tailing dumps (rain and snow melting).

The leachate from tailing dump is collected in front of the protective dam over drainage system and returned back in the lake. Water inflow through dam is controlled. Untimely control of inflow water leads to softening of embankment foot and dam accident.

Part of the water from tailing dump is also lost by infiltration - groundwater recharging or evaporation. The excess of clarified water, corresponding to the third class of water stream from the flotation lake, is discharged through the overflow 
body and collector into the river (eg. FTD V. Krivelj). In case of lack of water in the flotation lake (minimum water for normal operation of the Flotation Plant), the required amount of water is taken from the Bor Lake (FTD RTH) and the Krivelj River (FTD V. Krivelj).

\section{CONSTRUCTION OF THE DAM}

\section{Construction of dams}

Hydrocyclones are installed along the dam on the fixed and stable stands at sufficient height of the existing dam crest elevation or on mobile platforms, which can be moved in any direction. During construction of the dam, the sand is quite compact. If this is not achieved, the additional compaction of sand or rolling are applied.

\section{Stability of the dam}

The dam is the main object of flotation tailing dumps, so its stability is vey important. The basic condition for dam stability is that the line of inflow water (depresion line) should not be closer to the outer slope of the dam. The inflow water line is obtained by reading the water level in the built-in piezometers. When the inflow water line approaches to the outer slope of dam, the rehabilitation of dam drainage system has to be done immediately. The task of drainage system is to collect and safely take the water that passes through the body of dam. The origin of water in the dam body can be from precipitation, hydrocyclone sand or from sedimentary lake.

\section{THE IMPACT OF THE FLOTATION TAILING DUMPS ON THE LIVING ENVIRONMENT OF BOR}

Flotation tailing dumps, both in the function of disposal or closed, present a constant threat to the ecological environmental factors of the catchment area downstream of the town of Bor. Accidents or incidents on the flotation tailing dumps are caused by natural disasters, technical failures, and the combination of both (3). On this occasion they result into ocurrence of dangerous threats to the environment where they pollute the water, soil, plants, destroy the habitat of animals and flood the houses of people (3).

Many environmental accidents happened in RTB Bor due to the damages on the flotation tailing dumps with pollution of rivers, soil and plants. Damages of accidents on the flotation tailing dumps happened due to the technical failures and natural disasters.

Causes of accidents in the Flotation Plant Bor and discharge the tailings into the Bor River in the seventies of the last century were classified in a group of technical failures (inadequate design solutions, unreliability of device operation in the production system and the lack of control and breaching the rules). Frequent power cuts during this period caused the failure of equipment, used in the Flotation Plant and flotation tailing dump Bor for disposal of tailings, so the flotation tailings was discharged into the Bor River.

Occurrence of sudden flooding waves with hazardous chemical contamination has led to the destruction of flora and fauna in the Bor River, and the arable areas on the banks of the river were flooded and the flotation tailings were deposited on them in the sediment higherr than $50 \mathrm{~cm}$. At the mouth of the Bor River into Timok, the thickness of tailings sediment is over 3 $\mathrm{m}$. Pollution of surfaces with flotation tailings was estimated at more than 2000 ha. These surfaces still have no ability to reinvent the vegetation after forty years.

\section{THE IMPACT OF THE FLOTATION TAILING DUMP BOR}

At the location of flotation tailing dump Bor, a disposal of flotation tailings 
was completed twenty years ago. A part of the surfaces of this tailing dump is recult vated, the second part is under the water and the third part of the flat surfaces are dried and present a major problem in the dry season when the northwest wind blows, whose speed is higher than $2 \mathrm{~m} / \mathrm{s}$ (Table 1), which is perpendicular to these surfaces. On that occasion, a cloud of dust rises and pollutes the southern part of the town of Bor and surrounding areas towards the village of Slatina.

Table 1 Wind frequencies and speeds in the area of Bor and surroundings

\begin{tabular}{|c|c|c|c|c|c|c|c|c|c|}
\hline Direction & N & NNE & NE & ENE & E & ESE & SE & SSE & S \\
\hline F $\%$ & 0.6 & 0.3 & 0.3 & 2.5 & 6.6 & 1.0 & 0.4 & 0.5 & 3.4 \\
\hline W m/s & 1.6 & 1.54 & 1.88 & 1.86 & 1.64 & 0.74 & 1.06 & 0.96 & 1.66 \\
\hline Direction & SSW & SW & WSW & W & WNW & NW & NNW & C & SSW \\
\hline F \% & 1.1 & 0.4 & 1.1 & 6.6 & 8.9 & 6.7 & 1.3 & 41.7 & 1.1 \\
\hline W m/s & 1.18 & 1.04 & 1.32 & 2.06 & 2.54 & 2.5 & 1.76 & - & 1.18 \\
\hline
\end{tabular}

Determining the dust emissions from the open dry areas of the flotation tailing dump in $\mathrm{W}$, WNW and NW direction of wind was done on the basis of specific dust rising per formula (1):

$$
\mathrm{q}=\mathrm{g} \cdot \mathrm{F}, \mathrm{mg} / \mathrm{s}
$$

Where:

$\mathrm{g}$ - value of specific dust rising for dif ferent wind speeds over the open areas, $(\mathrm{g}=0.2 \div 0.5)$

$\mathrm{F}$ - open area over which the wind blows with speed $\mathrm{V}>2 \mathrm{~m} / \mathrm{s}$

$\mathrm{q}$ - dust emission from the tailingdum surface, $\mathrm{mg} / \mathrm{s}$

The results of calculation are shown in Table 2 .

Table 2 Range of dust in the environment of the FTD Bor

\begin{tabular}{|c|c|c|c|c|}
\hline Wind direction & $\begin{array}{c}\text { Wind speed } \\
W_{s}(\mathrm{~m} / \mathbf{s})\end{array}$ & $\begin{array}{c}\mathbf{K} \cdot \sum \mathbf{q} \\
(\mathbf{m g} / \mathbf{s})\end{array}$ & $\psi$ & $\mathbf{L}(\mathbf{m})$ \\
\hline W & 2.06 & 109662 & 0.3127 & 230 \\
\hline WNW & 2.54 & 274152 & 0.3343 & 400 \\
\hline NW & 2.5 & 219321 & 0.3325 & 330 \\
\hline Wind direction & $\begin{array}{c}C_{M D K}-C_{o} \\
\left(\mathrm{mg} / \mathrm{m}^{3}\right)\end{array}$ & $\mathbf{X}(\mathbf{m})$ & In direction & q $\mathrm{mg} / \mathrm{s}$ \\
\hline $\mathrm{W}$ & 0.11 & 6728.8 & $E$ & 36554 \\
\hline WNW & 0.11 & 7337.8 & ESE & 91384 \\
\hline NW & 0.11 & 7268.5 & SE & 73107 \\
\hline
\end{tabular}

Figure 1 shows the zone of dust impact from the flotation tailing dump Bor.
The affected areas of the forecasted zone of dust impact from the flotation tailing dump amounted to $18361074 \mathrm{~m}^{2}$. 


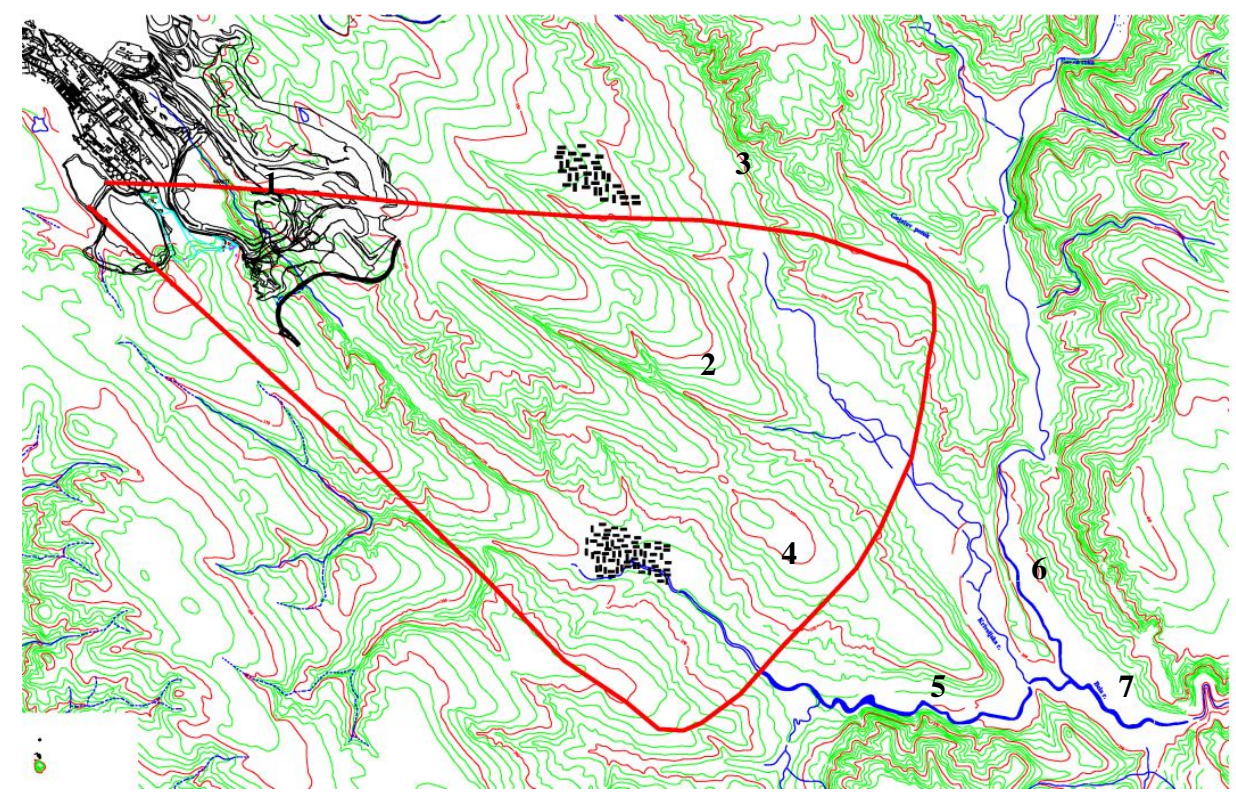

Figure 1 Affected zone of dust impact from the flotation tailing dump Bor

Legend:1. flotation tailing dump Bor, 2. dust influence zone, -3. village Oštrelj, 4. village Slatina, 5. Bor River, 6. Krivelj River, 7. Bela River

\section{THE IMPACT OF THE FLOTATION \\ TAILING DUMP RTH}

Leachate of the flotation tailing dump $\mathrm{RTH}$ affects the pollution of the Bor River and groundwater, but it can cause an accident at Dams 1 and 2.

Accident on dams can occur in the normal course of operation or after termination of tailings disposal. Disruption to the field stability of Dam 1 may cause the exploitation of smelting slag near the tailing dump and the earthquake intensity higher than 8 degrees of the Mercalli scale. The accident on Dam 1 would cause the filling of the open pit Slag Depot with flotation lime and stoppage of slag exploitation as well as backfilling the space of abandoned open pit Bor. On this occasion, the underground mien Jama Bor would be seriously endanegered and disposal of tailings from the Open Pit Veliki Krivelj over the transport and disposal systems into the open pit Bor.

Breakthrough on Dam 2 and accident in the flotation tailing dump RTH may occur due to the failure of drainage system below Dam 2. Breakthrough of flotation slime (flotation tailings and water) through Dam 2 would result in filling of depression downstream of Dam 2 of the flotation tailing dump RTH and endangering the local embankment and road Bor Oštrelj and railroad Bor - Zajecar and Bor River.

Stability of peripheral embankment of the flotation tailing dump RTH depends on the position of sedimentary lake within the accumulation area. If the water of sed 
imentary lake touch the inner slope of peripheral embankment of on the west side of tailing dump, the tailing dump stability is brought into a question, especially during an earthquake above 8 degrees of the Mercalli scale. Penetration of the flotation slime through the circumferential embankment would cause a threat of industrial road and railroad and there would be a spill of slime in the Bor River. Flood wave would threat the village of Slatina and land and water in the coastal areas of the Bor River to Timok, and then the mouth of Timok into Danube.

Accidents on the flotation tailing dump RTH may arise due to the occurrence of damages on concrete covers that are not resistant to acid. Accient occure in a contact of cover ex-connectors (manholes) II and III on the tunnel (deviation) of the Bor River, built for the needs of drainage the former open pit of the ore body $\mathrm{H}$, and now the accumulation area of the flotation tailing dump RTH, with the acidic medium (flotation tailings seepage acid water). Height of leakage column of fluid mass during possible accident would amount to $85.8 \mathrm{~m}$, and volume of leaked fluid mass from the landfill through the tunnel (deviation of the river) into the Bor River would be approximately $2736945 \mathrm{~m}^{3}$. Cross-section of the hole of damage (Connection II to the Bor River tunnel) has radius on surface area of $109.89 \mathrm{~m}$, while the radius of hole of damage is 0.84 .

The average speed of fluid mass leakage in possible accident would amount to $\mathrm{W}=20.42 \mathrm{~m} / \mathrm{s}$, while the average amount of leakage would be $\mathrm{Q}=44.42 \mathrm{~m}^{3} / \mathrm{s}$. Total flood wave of the Bor River would amount to $Q_{\text {total }}=45.00 \mathrm{~m}^{3} / \mathrm{s}$. Concentration of pollution with flotation tailings in the Bor River at the beginning of breakthrough would amount to $59.81 \%$. Fore casting the length of flood wave during possible accident at the flotation tailing dump RTH was made on the basis of: the study the situational map, scale 1: 50000 of the Bor River and Timok valley, analysis the actual flood wave range in the previous accident situation at the flotation tailing dump Bor, when there was a spill of flotation tailings on surfaces in the valley of these rivers and the mathematical model $\mathrm{d}_{\mathrm{sr}}=0.2156 \mathrm{~L}^{-0.8262}(\mathrm{~m})$ for the actual flood wave of the river Pek that occurred in 1974, creating a sudden abyss in the Karst landscape at the flotation tailing dump Valja Fundata Majdanpek. This sequence of events is mathematically modeled by the Copper Institute Bor in 2006. Based on a mathematical model for the flotation tailing dump Valaj Fundata, comparative method predicted the scope and course of the flood wave flow of the Bor River and Timok. The range of flood wave is influenced by the speed of river by sections, which are variable, then the slopes of the river banks, narrow river beds, the speed of spilled flood wave from the riverbed on flooded areas and the median diameter of flotation tailings. Height of flood wave can be explicitly expressed in a finction of form and cross-section of waterbed at a downstream profile and the average water level which is added to the estimated volume of fluid mass leakage from the landfill mass.

Dry surfaces of the flotation tailing dump RTH present a threat to the southern part of the town where the wind from the northwest direction raises dust and contaminate large areas. The range of dust from the flotation tailing dump RTH is given in Table 3.

Threatened areas of forecasted zone of dust impact from the flotation tailing dump RTH amount to $3713408 \mathrm{~m}^{2}$. 
Table 3 Range of dust in the environment of the FTD RTH

\begin{tabular}{|c|c|c|c|c|}
\hline Wind direction & $\begin{array}{c}\text { Wind speed } \\
\mathbf{W}_{\mathbf{s}}(\mathbf{m} / \mathbf{s})\end{array}$ & $\begin{array}{c}\mathbf{K} \cdot \sum \mathbf{q} \\
(\mathbf{m g} / \mathbf{s})\end{array}$ & $\Psi$ & $\mathbf{L}(\mathbf{m})$ \\
\hline W & 2.06 & 43600 & 0.3127 & 445 \\
\hline WNW & 2.54 & 108750 & 0.3343 & 250 \\
\hline NW & 2.5 & 87000 & 0.3325 & 245 \\
\hline Wind direction & $\begin{array}{c}\mathbf{C}_{\mathbf{M D K}}-\mathbf{C}_{\mathbf{o}} \\
\left(\mathbf{m g} / \mathbf{m}^{\mathbf{3}}\right)\end{array}$ & $\mathbf{X}(\mathbf{m})$ & In direction & $\mathbf{q}(\mathbf{m g} / \mathbf{s})$ \\
\hline W & 0.11 & 1382.7 & E & 14500 \\
\hline WNW & 0.11 & 4657.2 & ESE & 36250 \\
\hline NW & 0.11 & 3883.5 & SE & 29000 \\
\hline
\end{tabular}

Figure 2 shows the zone of dust impact from the flotation tailing dump RTH.

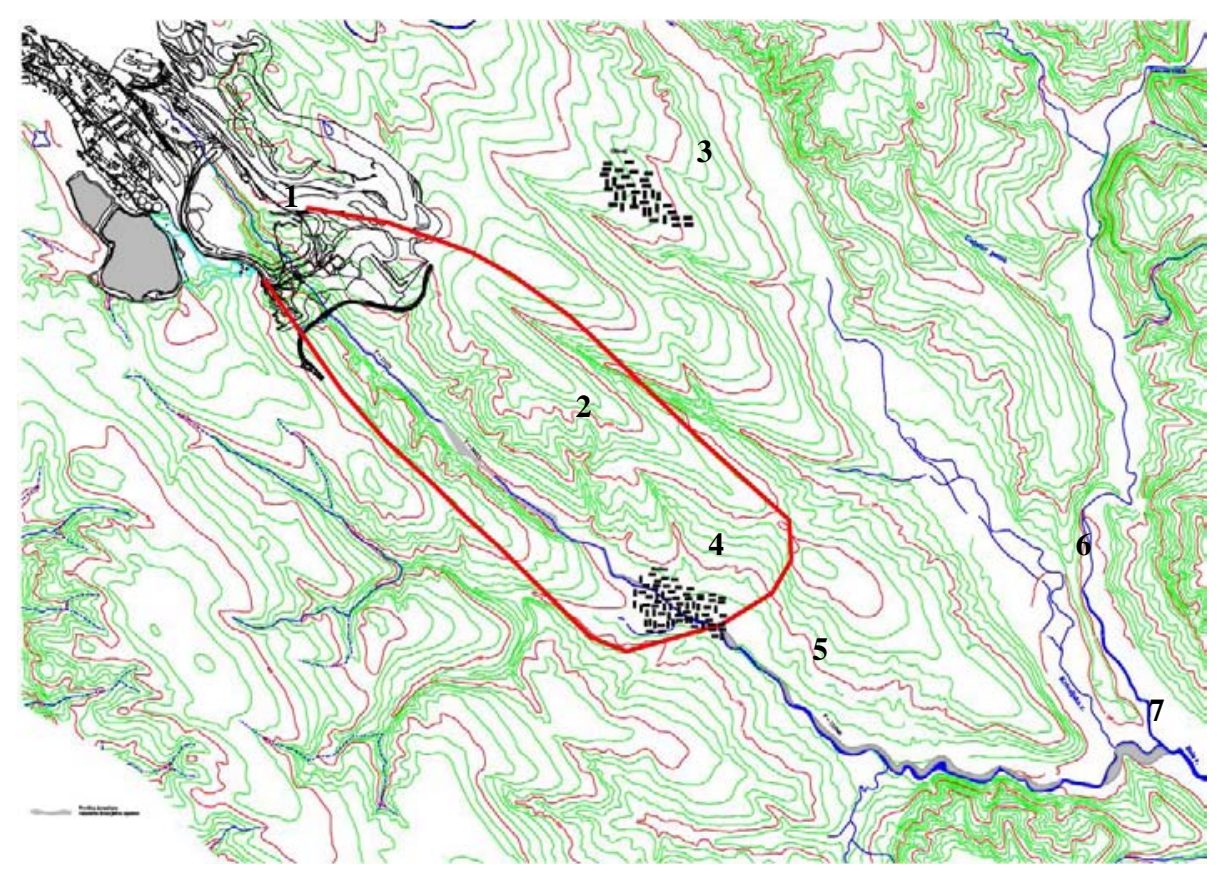

Figure 2 Zone of dust impact from the flotation tailing dump RTH

Legend:1. flotation tailing dump RTH, 2. dust influence zone, — 3. village Oštrelj, 4. village Slatina, 5. Bor River, 6. Krivelj River, 7. Bela River

\section{FORECAST THE DUST RANGE IN \\ THE ENVIRONMENT OF THE \\ FLOTATION TAILING DUMP \\ VELIKI KRIVELJ}

Flotation tailing dump V. Krivelj is a great threat to the village Oštrelj and surroundings. Hazards are expressed through contaminated water of the Krivelj River that runs through the tunnel and collector tailing below the tailing dump. Wind from 
the northwest direction has the average speed higher than the critical wind speed under whose dynamic force can raise the dust from Dam 3A of the flotation tailing dump. Its direction is perpendicular to the length of dam and the area of village
Oštrelj is situated in its direction.

Dust emission is $\mathrm{q}=105000 \mathrm{mg} / \mathrm{s}$.

The range of dust concentration above C > $0.12 \mathrm{mg} / \mathrm{m}^{3}$ in all wind directions is shown in Table 1, and Table 4 presents the results of calculations

Table 4 Range of dust in the environment of the FTD $V$. Krivelj

\begin{tabular}{|c|c|c|c|c|}
\hline Wind direction & $\begin{array}{c}\text { Wind speed } \\
\mathbf{W}_{\mathbf{s}}(\mathbf{m} / \mathbf{s})\end{array}$ & $\begin{array}{c}\mathbf{K} \cdot \sum \mathbf{q} \\
(\mathbf{m g} / \mathbf{s})\end{array}$ & $\boldsymbol{\Psi}$ & $\mathbf{L}(\mathbf{m})$ \\
\hline $\mathrm{W}$ & 2.06 & 136450 & 0.3127 & 485 \\
\hline $\mathrm{WNW}$ & 2.54 & 338625 & 0.3343 & 594 \\
\hline $\mathrm{NW}$ & 2.5 & 273000 & 0.3325 & 600 \\
\hline Wind direction & $\begin{array}{c}\mathbf{C}_{\mathbf{M D K}} \mathbf{- \mathbf { C } _ { \mathbf { o } }} \\
\left(\mathbf{m g} / \mathbf{m}^{\mathbf{3}}\right)\end{array}$ & $\mathbf{X}(\mathbf{m})$ & In direction & $\mathbf{q}(\mathbf{m g} / \mathbf{s})$ \\
\hline $\mathrm{W}$ & 0.11 & 3970.5 & $\mathrm{E}$ & 46150 \\
\hline $\mathrm{WNW}$ & 0.11 & 6103.4 & $\mathrm{ESE}$ & 112875 \\
\hline $\mathrm{NW}$ & 0.11 & 4976.1 & $\mathrm{SE}$ & 91000 \\
\hline
\end{tabular}

Figure 3 shows the zone of dust impact from the flotation tailing dump Veliki Krivelj.

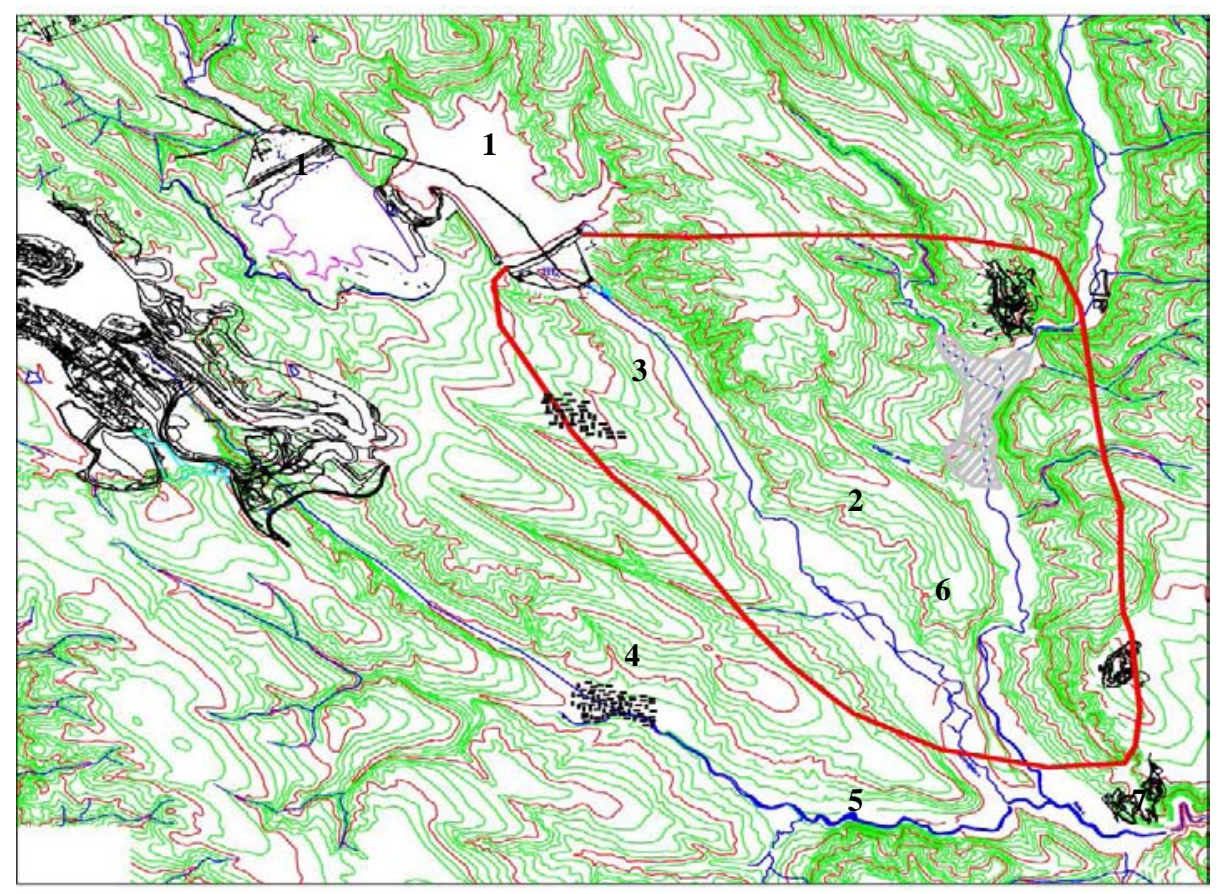

Figure 3 Zone of dust impact from the flotation tailing dump Veliki Krivelj

Legend:1. flotation tailing dump Veliki Krivelj, 2. dust influence zone, -3. village Ořtrelj, 4. village Slatina, 5. Bor River, 6. Krivelj River, 7. Bela River 
Surface area of forecasted zone of dust impact from the flotation tailing dump Veliki Krivelj amounts to $16077805 \mathrm{~m}^{2}$.

Collector below Field 2 of the flotation tailing dump Veliki Krivelj also presents a riskr to the environment where, due to inadequate design solutions in the construction of Dam 3A, the cracks occurred. The walls of collector below Dam 3 were strengthened with monolithic lining of 40 $\mathrm{cm}$, and the cross section of collector is reduced from 3 to $2.20 \mathrm{~m}$. There is a risk of collector on a part with overflow the body and, according to the the prognosis, a breakthrough of flotation tailing may arise into the Krivelj River, which is a tributary of the Bor River, and water pollution to the Danube.

Height of leakage column of fluid mass during possible accident would amount to $85.22 \mathrm{~m}$, and volume of leaked fluid mass from the landfill through the collector into the Krivelj River, Bor River and Timok would be approximately 2677 $246.3 \mathrm{~m}^{3}$. Cross-section of the hole of damage has radius on surface area of $104.4 \mathrm{~m}$, while the radius of hole of damage is $0.83 \mathrm{~m}$ according to the forecast.

The average speed of fluid mass leakage in possible accident would amount to $\mathrm{W}=29.37 \mathrm{~m} / \mathrm{s}$, while the average amount of leakage would be $\mathrm{Q}=64.6 \mathrm{~m}^{3} / \mathrm{s}$. Total flood wave of the Krivelj River would amount to $Q_{\text {total }}=47.64 \mathrm{~m}^{3} / \mathrm{s}$. Concentration of pollution with flotation tailings in the Krivelj River at the beginning of breakthrough would amount to $64.62 \%$.

\section{MEASURES OF PROTECTION}

In order to protect the environment of Bor from pollution of the flotation tailing dumps: Bor, RTH and V. Krivelj, it is necessarty to do the following:

- To recultivate the remaining areas at the flotation tailing dump Bor using the optimum reclamation with the phases of agrotechnical, technical and biological reclamation,
- To perform the constant visual observations in the exploitation of slag and to keep a diary on observations in the field. This would take account of the stability of Dam 2 of the flotation tailing dump RTH,

- To keep constantly in a function the drainage system below Dam 1 of the flotation tailing dump RTH and to return back the leachate into sedimentary lake using the pumps,

- To keep away the water from sedimentary lake of the flotation tailing dump RTH from inner slope of the peripheral embankment of the flotation tailing dump RTH,

- To recultivate the final areas of the flotation tailing dump RTH using the optimum reclamation upon completion the process of tailings disposal,

- To recultivate Dam 3A of the flotation tailing dump Veliki Krivelj using the optimum reclamation,

- To put out of operation the existing overflow body, and to construct the new one on the field on the west of the Dam 3A of the flotation tailing dump Veliki Krivelj,

- To put out of operation the existing collector and to construct a tunnel on a firm field which will fit into the existing tunnel,

- And to recultivate the final areas of Dam 1A and Dam2A after upgrading the Field 1 of the flotation tailing dump Veliki Krivelj,

- To construct a protective dam downstream from the mouth of the Krivelj River into Bor River that would pass the ewater and keep the flotation sand and mud, what would protect the fertile areas around the river Timok against pollution.

\section{CONCLUSION}

A great attention should be paid to the environmental protection of the town of Bor in the southeastern Serbia, water sur 
faces and catchment area downstream of the tailing dumps (the river Timok), because the flotation tailing dumps are a constant danger, affected by the natural factors (disasters) and technical failures during design and construction of the same. Due to this reason, it is necessary to fully utilize the disposal space that does not take up the new areas and pollute the new river flows (4).

\section{REFERENCES}

[1] D. Kržanović, M. Mikić, M. Ljubojev, Analysis the Spatial Position of Mining Facilities of the Veliki Krivelj Mine to the Proposed Tunnel Route for Relocation the Krivelj River, Mining Engineering, 3(2011), pp. 95-101.

[2] Kržanović D., Mikić M., Ljubojev M., Analysis of Development Effects of the Veliki Krivelj Mine on Construction the new facilities for Deviation the Krivelj River, Mining Engineering, 4(2011), pp. 57-65.

[3] Lekovski R., Bugarin M., Mikić M., Causes of Accidents on the Flotation Tailing Dumps in Serbia, Mining engineering, 3(2012), pp. 107-114.

[4] Kržanović D., Mikić M., Ljubojev M., Auscultation and Zone Monitoring of Current Collector of the Krivelj River
Below Flotation Tailing Dump Veliki Krivelj, $12^{\text {th }}$ Scientific Geocon-ference SGEM 2012, proceedings volume I, Geology Exploration and Mining, pp. 465-472.

[5] R. Lekovski, M. Mikić, M. Martinović, Environmental Protection Against the Influence of Quartz Sandstone Tailing Dump part Donja Bela Reka, Mining Engineering, 1(2009), pp. 107-114.

[6] R. Rajkovic, D. Kržanović, M. Mikić, Application the Software Package Whittle for Determining the Mineable Reserves of the Copper Deposit South Mining District Majdanpek, Serbia, Mining Engineering, 3(2012), pp. 123131.

[7] M. Ljubojev, D. Ignjatović, L. Dj. Ignjatović, V. Ljubojev, Preparations for Investigation the Tunnel Axis and Field Surveying, Mining engineering, 1(2011), pp. 139-143

[8] M. Ljubojev, D. Ignjatović, L. Dj. Ignjatović, Proposal of Cross Section for the Krivelj River Tunnel, Mining Engineering, 1(2011), pp. 79-85

[9] D. Ignjatović, M. Ljubojev, L. Đ. Ignjatović, J. Petrović Rock Mass Classification Before the Tunnel Construction (per Wicham and Bienawski), Mining Engineering, 1(2011), pp. 69-73. 


\begin{tabular}{ll}
\hline \hline INSTITUT ZA RUDARSTVO I METALURGIJU BOR & ISSN: 2334-8836 \\
& UDK: 622 \\
\hline \hline
\end{tabular}

\title{
UTICAJ FLOTACIJSKIH JALOVIŠTA NA ŽIVOTNU SREDINU BORA I MERE ZAŠTITE***
}

\begin{abstract}
Izvod
U jugoistočnoj Srbiji na području opštine Bor postoje tri flotacijska jalovišta: FJ Bor, FJ RTH (rudno telo H) i FJ Veliki Krivelj. Flotacijsko jalovište Bor je napušteno, delimično rekultivirano. Druga dva su aktivna flotacijska jalovišta. Sva tri flotacijska jalovišta predstavljaju ozbiljne zagađivače vazduha, vode $i$ zemljišta. Zone uticaje od prašine ovih jalovišta ugrožavaju velike površine u smeru dominantnog vetra iz severozapadnog pravca. Ugržene površine Zonom uticaja prašine sa: flotacijskog jalovišta Bor iznose $18.361 .074 \mathrm{~m}^{2}$, flotacijskog jalovišta rudnog tela $\mathrm{H} .713 .408 \mathrm{~m}^{2}$ i flotacijskog jalovišta Veliki Krivelj iznose 16.077.805 $\mathrm{m}^{2}$. Najefikasnije mere zaštite od podizanja prašine sa suvih površina putem vetra je primena optimalne rekultivacije sa fazama tehničke, agrotehničke i biološke rekultivacije.
\end{abstract}

Ključne reči: Flotacijska jalovišta, zaštita životne sredine, havarije, poplavni talas, zona uticaja,

\section{UVOD}

Priprema siromašne rude bakra $u$ flotaciji Bor i flotaciji Veliki Krivelj i koncentracija korisnih komponenata $\mathrm{u}$ vidu koncentrata bakra daje velike količine flotacijske jalovine, koja zahteva zauzimanje velikih prostora za njihovo skladištenje (deponovanje). Pri tome se koncentrat i jalovina dobijaju u smesi sa vodom u vidu pulpe. Koncentrat, kao korisna komponenta, odvodnjava se i skladišti u bunkerima $u$ samom postrojenju za dalju preradu $\mathrm{u}$ topionici bakra Bor, dok se jalovina do mesta odlaganja doprema pretežno hidraulički plastičnim cevima (FJRTH) i gravitaciono pomoću betonskih kanala (FJ V. Krivelj).
Za flotacijska jalovišta: Bor, RTH i Veliki Krivelj korišćeni su različiti oblici izgradnje flotacijskih jalovišta.

Najstarije flotacijsko jalovište Bor u početku je građeno kao dolinski tip u Borskom potoku, a zatim je za nadgradnju jalovišta primenjen kombinovano dolinski i ravničarski tip gradnje.

Flotacijsko jalovište RTH je u početku građeno kao dubinski tip jalovišta u otkopnom prostoru površinskog kopa RTH, a zatim je za nadgradnju korišćenra radijalna metoda a sada odstupna metoda. Flotacijsko jalovište Veliki Krivelj je dolinskog tipa, a brane su građene nastupnom metodom, dok

\footnotetext{
* Institut za rudarstvo i metalurgiju Bor, 19210 Bor, Srbija,

E-mail: ruzica.lekovski@gmail.com,mile.bugarin@irmbor.co.rs,miomir.mikic@irmbor.co.rs.

**: Ovaj rad je proistekao iz Projekta broj 33021 „Istraživanje i praćenje promena naponsko deformacionog stanja u stenskom masivu „in-situ“ oko podzemnih prostorija sa izradom modela sa posebnim osvrtom na tunel Kriveljske reke i Jame Bor", koga je finansiralo Ministarstvo za prosvetu, nauku i tehnološki razvoj Republike Srbije
} 
se nadogradnja vrši odstupnom metodom. $\mathrm{Za}$ deponovanje flotacijske jalovine, koja nastaje $\mathrm{u}$ procesu prerade rude, koristi se prostor dobijen pregrađivanjem doline Kriveljske reke (1). Flotacijska jalovina se u dubinski tip odlagala bez odvajanja čvrste od tečne faze, dok se u pregrađenim prostorima sa branama i obodnim nasipima vrši cikloniranje jalovine i odvojeno odlaganje. $\mathrm{U}$ akumulacioni prostor deponuje se samo preliv hidrociklona, a na branama pesak hidrociklona, koji ujedno služi kao materijal gradnju brana i obodnih nasipa do projektovane visine. Da bi se realizovalo novo proširenje flotacijskog jalovišta neophodno je prethodno izgraditi nove objekte za devijaciju Kriveljske reke, koji se nalaze u zoni flotacijskog jalovišta (2). Na ovaj način obezbedio bi se prostor za trajno deponovanje flotacijske jalovine. (2)

Zbog pouzdanosti rada i sigurne eksploatacije predviđenog prostora flotacijskog jalovišta u cilju zaštite životne sredine, odmah na početku izgradnje jalovišta sa veštačkim pregradama branama i nasipima gradila se:

- Osnovna (startna ili inicijalna) brana od čvtrstog (zemlje, peska ili lomljenog kamena) materijala koji predstavlja filtracionu i noseću osnovu,

- drenažni sistem u podini startne brane sa kolektorom za prihvatanje provirnih voda i isušivanje brane oko konture odlagališta,

- sistem za hidrotransport, cikloniranje mulja, izgradnju i nasipavanje brane i obodnog nasipa flotacijskog jalovišta i odlaganje sitnog mulja i vode u taložno jezero,

- sistem za evakuaciju izbistrene vode u proces flotacije,

- sistem za prihvatanje provirnih i prelivnih voda i njihovo vraćanje u taložno jezero ili na ponovno korišćenje. Zbog toga je bitno njihovo pravilno dimenzionisanje, projektovanje i solidna gradnja.
Odlaganje flotacijske jalovine u akumulacioni prostor obavlja se u zavisnosti od morfologije terena oko jalovišta, položaja taložnog jezera, dužine plaže, a ima za cilj maksimalno iskorišćenje raspoloživog prostora. Pri istakanju pulpe $\mathrm{u}$ akumulacioni prostor u operativnom radu vodi se računa da njen mlaz mehanički ne oštećuje nožicu unutrašnje kosine brane.

Unutar flotacijskog jalovišta formira se jezero u kome dolazi do sedimentacije mulja iz pulpe i izdvajanja čiste vode, čija najviša kota u odnosu na kotu brane mora biti manja za 3,0 do $5,0 \mathrm{~m}$ zavisno od slivne površine oko flotacijskog jalovišta. Izbistrena voda iz jezera se ponovo vraća $\mathrm{u}$ proces pomoću pumpi koje plutaju na splavu u jezeru.

U tehnološkom procesu flotacijske koncentracije koriste se $\mathrm{i}$ flotacioni reagensi koji predstavljaju različita hemijska jedinjenja i to: ksantogenati, alkalni metali, ditiofosfati, poliglikoli i kreč, koji služi za regulaciju $\mathrm{pH}$ vrednosti tehnološke vode. Flotacioni reagensi se apsorbuju na površinama čestica, a jedan deo ostaje u vodi u rastvorenom i dispergovanom stanju. Osim vode, koja se u jezero doprema iz flotacije sa flotacijskom jalovinom, jezero se puni i čistom vodom iz atmosferskih padavina $u$ okviru sliva flotacijskog jalovista (kiša i topljenja snega).

Procedne vode iz jalovista se prikupljaju ispred zaštitne brane preko drenažnog sistema i ponovo se vraćaju u jezero. Proviranje vode kroz branu je kontrolisano. Neblagovremena kontrola provirnih voda dovodi do razmekšavanja nožica nasipa i udesa brane.

Deo vode iz jalovišta se gubi i infiltracijom - prihranjivanjem podzemnih voda ili isparavanjem (evaporacijom). Višak izbistrene vode koja odgovara za treću klasu vodotoka iz flotacijskog jezera se ispušta preko prelivnog organa i kolektora u reku (primer FJ V. Krivelj). U slučaju manjka vode $\mathrm{u}$ flotacionom jezeru (minimum vode 
za normalan rad flotacije) potrebna količina vode se uzima iz Borskog jezera (FJ RTH) i iz Kriveljske reke (FJ V. Krivelj).

\section{GRADNJA BRANE}

\section{Konstrukcije brana}

Hidrocikloni se postavljaju duž brane na nepokretnim i stabilnim postoljima na dovoljnoj visini od postojeće kote krune brane ili na pokretnim platformama, koje se mogu pomerati u svim pravcima. Prilikom gradnje brane, pesak je dosta kompaktan. Ukoliko se to ne postiže, primenjuje se dodatno sabijanje peska, odnosno valjanje.

\section{Stabilnost brana}

Brana je glavni objekt flotacijskih odlagališta, pa je veoma važna njena stabilnost. Osnovni uslov za stabilnost brane je da linija provirnih voda (depresiona linija) ne sme da se približi spoljašnjoj kosini brane. Linija provirnih voda dobija se očitavanjem nivoa vode u ugrađenim pijezometrima. Kada se dogodi da provirna linija se približava spoljašnjoj kosini brane, odmah se mora pristupiti sanaciji drenažnog sistema brane. Zadatak drenažnog sistema je da prikupi i bezbedno odvede vodu koja prolazi kroz telo brane. Poreklo vode u telu brane može biti od atmasferilija, peska hidrociklona ili iz taložnog jezera.

\section{UTICAJ FLOTACIJSKIH JALOVIŠTA NA ŽIVOTNU SREDINU BORA}

Flotacijska odlagališta jalovine bilo da su u funkciji odlaganja ili su zatvorena, predstavljaju stalnu opasnost po ekološke faktore životne sredine slivnog područja nizvodno od grada Bora. Havarije ili udesi na flotacijskim jalovištima nastaju usled prirodnih nepogoda, tehničkih nedostataka i kombinacijom ova dva uzroka (3). Tom prilikom dovode do pojave opasnih rizika po životnu sredinu gde se zagađuju vode, zemljište, biljke, uništava se stanište životinja i plave kuće ljudima. (3)

U RTB Bor dogodilo se više udesa živothe sredine usled havarija na flotacijskim odlagalištima pri čemu su zagađene reke, zemljište i biljke. Havarije ili udesi na flotacijskim jalovištima nastali su usled tehničkih nedostataka i prirodnih nepogoda.

Uzroci havarije u Flotaciji Bor i ispuštanja flotacijske jalovine u Borsku reku 70 godina prošlog veka svrstani su u grupu tehničkih nedostataka (neadekvatnih projektnih rešenja, nepouzdanosti rada uređaja u proizvodnom sistemu i odsustva kontrole i nepoštovanja propisa). Česti nestanci električne energije u tom periodu izazvali su kvarove na opremi koja je korišćena u Flotaciji i na flotacijskom jalovištu Bor za odlaganje flotacijske jalovine, pa je flotacijska jalovina ispuštana u Borsku reku. Pojava iznenadnih poplavnih talasa sa opasnim hemijskim zagađenjem dovelo je do uništavanja flore $\mathrm{i}$ faune $\mathrm{u}$ Borskoj reci, a obradive površine na priobalju reke plavljene su i na njima je taložena flotacijska jalovina $u$ nanosu većem od $50 \mathrm{~cm}$. Na ušću Borske reke u Timok debljina sloja nanosa jalovine iznosi preko $3 \mathrm{~m}$. Zagađenost površina flotacijskom jalovinom procenjena je na više od 2.000 ha. Ove površine i posle četrdeset i više godina i dalje su bez sposobnosti za samoobnavljanje biljnog sveta.

\section{UTICAJ FLOTACIJSKOG JALOVIŠTA BOR}

$\mathrm{Na}$ lokaciji flotacijskog jalovišta Bor odlaganje flotacijske jalovine je završeno pre dvadeset godina. Deo površina ovog jalovišta su rekultivirane, drugi deo su pod vodom i treći deo ravnih površina su osušene i predstavljaju veliki problem u sušnom period kada duva severozapadni vetar, čija brzina je veća od $2 \mathrm{~m} / \mathrm{s}$ (tabela 1.) koji je 
upravan na ove površine. Tom prilikom uzdiže se oblak prašine i zagađuje južni deo grada Bora i okolne površine prema selu Slatini.

Tabela 1. Čestine i brzine vetrova na području Bora i okoline

\begin{tabular}{|c|c|c|c|c|c|c|c|c|c|}
\hline Pravac & N & NNE & NE & ENE & E & ESE & SE & SSE & S \\
\hline$\check{\text { C } \%}$ & 0,6 & 0,3 & 0,3 & 2,5 & 6,6 & 1,0 & 0,4 & 0,5 & 3,4 \\
\hline $\mathrm{V} \mathrm{m} / \mathrm{s}$ & 1,6 & 1,54 & 1,88 & 1,86 & 1,64 & 0,74 & 1,06 & 0,96 & 1,66 \\
\hline Pravac & SSW & SW & WSW & W & WNW & NW & NNW & C & SSW \\
\hline$\check{\text { C } \%}$ & 1,1 & 0,4 & 1,1 & 6,6 & 8,9 & 6,7 & 1,3 & 41,7 & 1,1 \\
\hline $\mathrm{V} \mathrm{m} / \mathrm{s}$ & 1,18 & 1,04 & 1,32 & 2,06 & 2,54 & 2,5 & 1,76 & - & 1,18 \\
\hline
\end{tabular}

Određivanje emisije prašine sa otvorenih suvih površina flotacijskog jalovišta na pravcu W, WNW, NW vetra izvršen je na osnovu specifičnog podizanja prašine po formuli (1):

$$
\mathrm{q}=\mathrm{g} \cdot \mathrm{F},(\mathrm{mg} / \mathrm{s})
$$

gde su:

g - vrednost specifičnih podizanja prašine za različite brzine vetra preko otvorenih površina, $(\mathrm{g}=0,2 \div 0,5)$

F - otvorena površina preko koje duva vetar brzinom $\mathrm{V}>2(\mathrm{~m} / \mathrm{s})$

q - emisija prašine sa površine jalovišta, $\mathrm{mg} / \mathrm{s}$

Rezultati proračuna prikazani su $\mathrm{u}$ tabeli 2 .

Tabela 2. Domet prašine u životnoj sredini FJ Bor

\begin{tabular}{|c|c|c|c|c|}
\hline $\begin{array}{c}\text { Pravac } \\
\text { vetra }\end{array}$ & $\begin{array}{c}\text { Brzina vetra } \\
\mathbf{W}_{\mathbf{s}}(\mathbf{m} / \mathbf{s})\end{array}$ & $\begin{array}{c}\mathbf{K} \cdot \sum \mathbf{q} \\
(\mathbf{m g} / \mathbf{s})\end{array}$ & $\boldsymbol{\Psi}$ & $\mathbf{L}(\mathbf{m})$ \\
\hline $\mathrm{W}$ & 2,06 & 109662 & 0,3127 & 230 \\
\hline $\mathrm{WNW}$ & 2,54 & 274152 & 0,3343 & 400 \\
\hline $\mathrm{NW}$ & 2,5 & 219321 & 0,3325 & 330 \\
\hline $\begin{array}{c}\text { Pravac } \\
\text { vetra }\end{array}$ & $\begin{array}{c}\mathbf{C}_{\mathbf{M D K}}-\mathbf{C}_{\mathbf{~}} \\
\left(\mathbf{m g} / \mathbf{m}^{\mathbf{3}}\right)\end{array}$ & $\mathbf{X}(\mathbf{m})$ & $\mathbf{U} \mathbf{p r a v c u}$ & $\mathbf{q}(\mathbf{m g} / \mathbf{s})$ \\
\hline $\mathrm{W}$ & 0,11 & 6728,8 & $\mathrm{E}$ & 36554 \\
\hline $\mathrm{WNW}$ & 0,11 & 7337,8 & $\mathrm{ESE}$ & 91384 \\
\hline $\mathrm{NW}$ & 0,11 & 7268,5 & $\mathrm{SE}$ & 73107 \\
\hline
\end{tabular}

Na slici 1 je prikazana zona uticaja prašine flotacijskog jalovišta Bor.
Ugrožene površine prognozirane zone uticaja prašine sa flotacijskog jalovišta Bor iznosiće $18.361 .074 \mathrm{~m}^{2}$. 


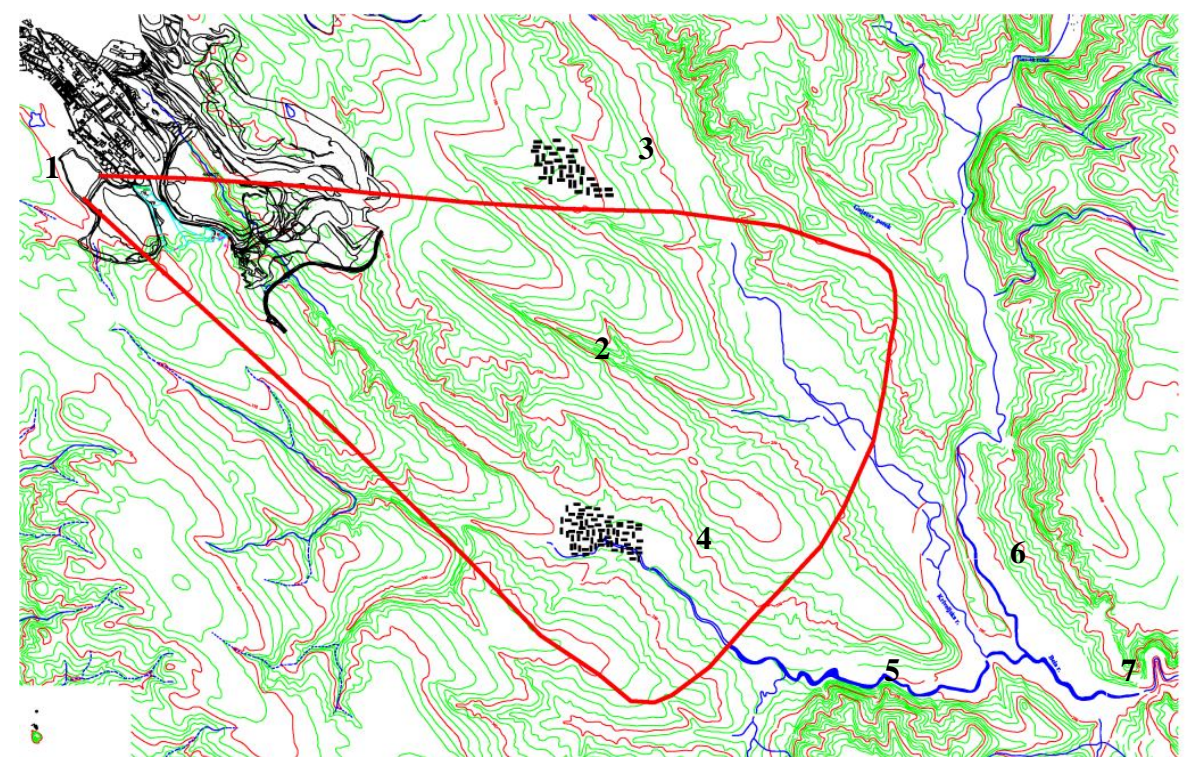

SI. 1. Zona uticaja od prašine sa flotacijskog jalovišta Bor

Legenda: 1. FJ Bor, 2. zona uticaja prašine, 3. Oštrelj, 4. Slatina, 5. Borska reka, 6. Kriveljska reka, 7. Bela reka

\section{UTICAJ FLOTACIJSKOG \\ JALOVIŠTA RTH}

Procedne vode FJ RTH utiču na zagađenje Borske reke I podzemnih voda, ali mogu izazvati udes na branama 1 i 2.

Udes na branama može nastati u toku redovnog rada ili posle prestanka odlaganja flotacijske jalovine. Poremećaj stabilnosti terena na brani 1 može izazvati eksploatacija topioničke šljake u neposrednoj blizini jalovišta i zemljotres intenziteta većeg od 8 stepeni Merkalijeve skale. Udes na brani 1 izazvao bi zapunjavanje površinskog kopa Depo šljake 1 flotacijskim muljem i prekid eksploatacije šljake kao i zatrpavanje otkopnog prostora napuštenog površinskog kopa Bor. Tom prilikom ozbiljno bi bila ugrožena Jama Bor i odlaganje jalovine sa PK Veliki Krivelj preko transportnog sistema i odlagača u površinski kop Bor.

Do proloma na brani 2 i udesa na flotacijskom jalovištu RTH može doći usled kvara na drenažnom sistemu ispod brane 2 . Probojem flotacijskog mulja (flotacijske jalovine i vode) kroz branu 2 došlo bi do zapune depresije nizvodno od brane $2 \mathrm{FJ}$ RTH i ugrožavanja nasipa i lokalnog puta Bor - Oštrelj i pruge Bor - Zaječar i Borsku reku.

Stabilnost obodnog nasipa FJ RTH zavisi od položaja taložnog jezera unutar akumulacionog prostora. Ukoliko vode taložnog jezera dodiruju unutrašnju kosinu obodnog nasipa na zapadnoj strani jalovišta, stabilnost jalovišta je dovedena u pitanja, a naročito za vreme zemljotresa iznad 8 stepeni Merkalijeve skale. Prodor flotacijskog mulja kroz obodni nasip izazvao bi ugrožavanje industrijskog puta i industrijske pruge i došlo bi do izlivanja mulja u Borsku reku. Poplavni talas bi ugrozio selo Slatinu i zemljište i vode u 
priobalju Borske reke do Timoka, a zatim i ušće Timoka u Dunav.

Havarije na flotacijskom jalovištu RTH mogu nastati usled pojave oštećenja na poklopcima od betona koji je kiselo neotporan. Havarija nastaje pri kontaktu poklopca bivših priključaka (okana) II i III na tunelu (devijaciji) Borske Reke izgrađenih za potrebe odvodnjavanja bivšeg površinskog kopa rudnog tela $\mathrm{H}$, a sada akumulacioni prostor FJ RTH, sa kiselom sredinom (flotacijskom jalovinom i procednim kiselim vodama). Visina stuba isticanja fluidne mase prilikom mogućeg udesa iznosio bi $85,8 \mathrm{~m}$, a zapremina istekle fluidne mase iz odlagališta preko tunela (devijacije reke) u Borsku Reku iznosila bi oko 2.736.945 $\mathrm{m}^{3}$. Poprečni presek otvora oštećenja (Priključak II na tunel Borske Reke, koji je poluprečnika na površini $109,89 \mathrm{~m}$, dok je poluprečnik otvora oštećenja $0,84 \mathrm{~m}$.

Prosečna brzina isticanja fluidne mase prilikom mogućeg udesa iznosila bi $\mathrm{W}=20,42 \mathrm{~m} / \mathrm{s}$, dok bi prosečna količina isticanja bila $\mathrm{Q}=44,42 \mathrm{~m}^{3} / \mathrm{s}$. Ukupan poplavni talas Borske Reke iznosio bi $\mathrm{Q}_{\mathrm{u}}=45,00 \mathrm{~m}^{3} / \mathrm{s}$. Koncentracija zagađenja flotacijskom jalovinom u Borskoj Reci na početku proboja iznosila bi 59,81\%. Prognoziranje dužine poplavnog talasa pri mogućem akcidentu na FJ RTH izvršen je na osnovu: izučavanja situacione karte razmere 1:50000 doline Borske reke i Timoka, analize stvarnih dometa poplavnog talasa pri ranijim eksidentnim sitacijama na flotacijskom jalovištu Bor kada je došlo do izlivanja flotacijske jalovine na površine $u$ dolini ovih reka i matematičkog modela $\mathrm{d}_{\mathrm{sI}}=0,2156 \mathrm{~L}^{-0,8262}(\mathrm{~m})$ za stvarni poplavni talas reke Pek koji se dogodio 1974. Godine stvaranjem iznenadnim ponorom u kraškom terenu na FJ Valja Fundata Majdanpek. Ovaj tok događaja matematički je modeliran u Institutu za bakar Bor 2006 godine. Na osnovu matematičkog modela za flotacijsko jalovište Valja Fundata, komparativnom metodom prognoziran je domet i tok odvijanja poplavnog talasa Borske reke i Timoka. Na domet poplavnog talasa uticaj imaju i brzine matice toka reka po deonicama, koje su promenljive, zatim nagibi obala reka, sužena korita reka, brzine izlivenog poplavnog talasa iz korita reke na poplavljenim površinama i srednji prečnik čestice flotacijske jalovine. Visina poplavnog talasa eksplicitno se može izraziti u funkciji oblika i površine poprečnog preseka korita vodotoka na nekom nizvodnom profilu i prosečnog vodostaja vodotoka kome se dodaje procenjena količina isticanja fludne mase sa odlagališta.

Suve površine flotacijskog jalovišta RTH predstavljaju opasnost za južni deo grada gde se vetrom iz severozapadnog pravca podiže prašina i zagađuju velike površine. Domet prašine sa FJ RTH dat je u tabeli 3 .

Ugrožene površine prognozirane zone uticaja prašine sa flotacijskog jalovišta RTH iznose $3.713 .408 \mathrm{~m}^{2}$.

Tabela 3. Domet prašine u životnoj sredini FJ RTH

\begin{tabular}{|c|c|c|c|c|}
\hline $\begin{array}{c}\text { Pravac } \\
\text { vetra }\end{array}$ & $\begin{array}{c}\text { Brzina vetra } \\
\mathbf{W}_{\mathbf{s}}(\mathbf{m} / \mathbf{s})\end{array}$ & $\begin{array}{c}\mathbf{K} \cdot \sum \mathbf{q} \\
(\mathbf{m g} / \mathbf{s})\end{array}$ & $\boldsymbol{\Psi}$ & $\mathbf{L}(\mathbf{m})$ \\
\hline $\mathrm{W}$ & 2,06 & 43600 & 0,3127 & 445 \\
\hline $\mathrm{WNW}$ & 2,54 & 108750 & 0,3343 & 250 \\
\hline $\mathrm{NW}$ & 2,5 & 87000 & 0,3325 & 245 \\
\hline $\begin{array}{c}\text { Pravac } \\
\text { vetra }\end{array}$ & $\begin{array}{c}\mathbf{C}_{\mathrm{MDK}}-\mathbf{C}_{\mathbf{o}} \\
\left(\mathbf{m g} / \mathbf{m}^{\mathbf{3}}\right)\end{array}$ & $\mathbf{X}(\mathbf{m})$ & $\mathbf{U} \mathbf{p r a v c u}$ & $\mathbf{q}(\mathbf{m g} / \mathbf{s})$ \\
\hline $\mathrm{W}$ & 0,11 & 1382,7 & $\mathrm{E}$ & 14500 \\
\hline $\mathrm{WNW}$ & 0,11 & 4657,2 & $\mathrm{ESE}$ & 36250 \\
\hline $\mathrm{NW}$ & 0,11 & 3883,5 & $\mathrm{SE}$ & 29000 \\
\hline
\end{tabular}


Na slici 2 je prikazana zona uticaja prašine flotacijskog jalovišta Bor.

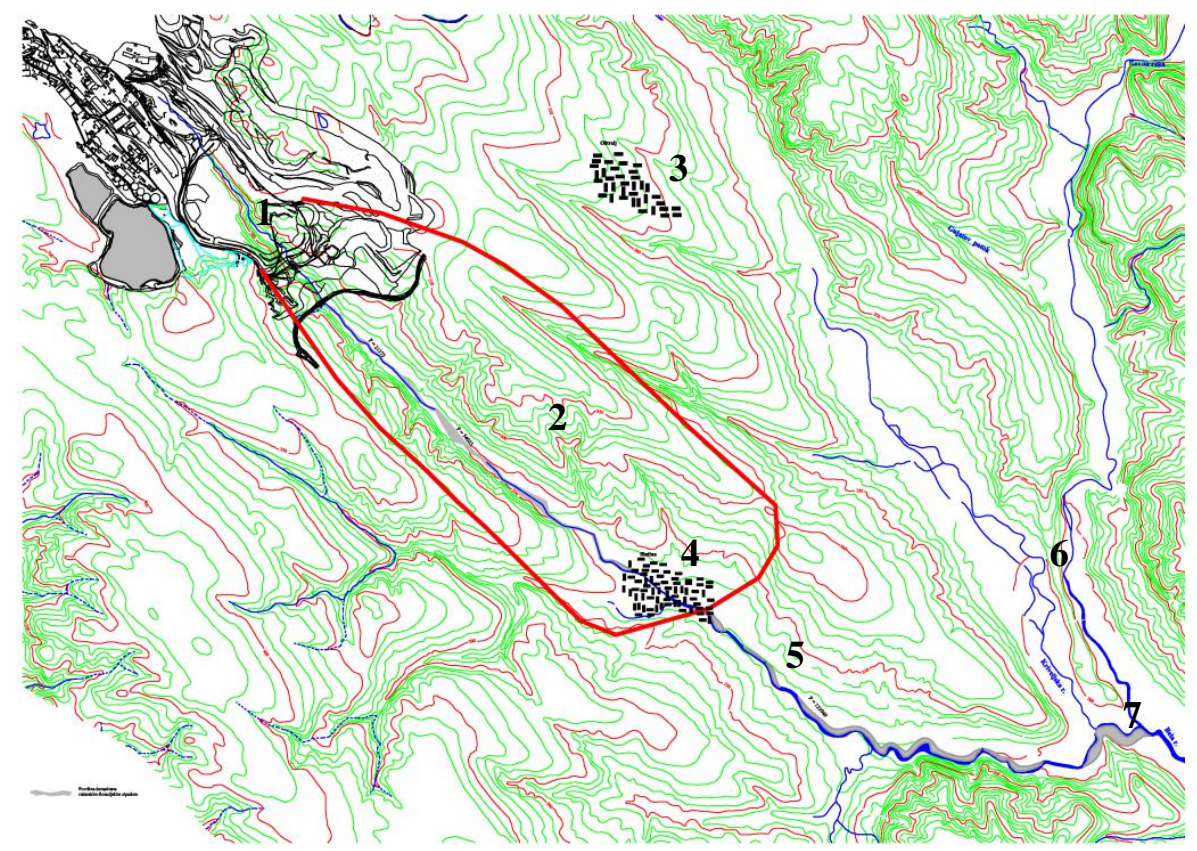

Sl. 2. Zona uticaja prašine sa flotacijskog jalovišta RTH.

Legenda: 1. FJ RTH, 2. zona uticaja prašine, 3. Oštrelj, 4. Slatina, 5. Borska reka, 6. Kriveljska reka, 7. Bela reka

\section{PROGNOZA DOMETA PRAŠINE \\ U ŽIVOTNOJ SREDINI \\ FLOTACIJSKOG JALOVIŠTA VELIKI KRIVELJ}

Flotacijsko jalovište V. Krivelj predstavlja veliku opasnost za selo Oštrelj i okolinu. Opasnosti se izražavaju kroz zagađene vode Kriveljske reke koja tunelom i kolektorom teče ispod jalovišta. Vetar iz severozapadnog pravca ima prosečnu brzinu veću od kritične brzine vetra pod čijom se dinamičkom silom može da podiže prašina sa brane $3 \mathrm{~A}$, flota- cijskog jalovišta. Njegov smer je upravan na dužinu brane i u njegovom smeru leži atar sela Oštrelj.

Emisija prašine iznosi q=105.000 mg/s

Domet koncentracije prašine iznad C $>0,12 \mathrm{mg} / \mathrm{m}^{3}$ u svim pravcima vetrova prika-zan je u tabeli 1 a u tabeli 4 su dati rezultati proračuna. 
Tabela 4. Domet prašine u životnoj sredini FJ V. Krivelj

\begin{tabular}{|c|c|c|c|c|}
\hline $\begin{array}{c}\text { Pravac } \\
\text { vetra }\end{array}$ & $\begin{array}{c}\text { Brzina } \\
\text { vetra } \\
\mathbf{W}_{\mathbf{s}}(\mathbf{m} / \mathbf{s})\end{array}$ & $\begin{array}{c}\mathbf{K} \cdot \sum \mathbf{q} \\
(\mathbf{m g} / \mathbf{s})\end{array}$ & $\boldsymbol{\Psi}$ & $\mathbf{L}(\mathbf{m})$ \\
\hline $\mathrm{W}$ & 2,06 & 136450 & 0,3127 & 485 \\
\hline $\mathrm{WNW}$ & 2,54 & 338625 & 0,3343 & 594 \\
\hline NW & 2,5 & 273000 & 0,3325 & 600 \\
\hline $\begin{array}{c}\text { Pravac } \\
\text { vetra }\end{array}$ & $\begin{array}{c}\mathbf{C}_{\mathbf{M D K}}-\mathbf{C}_{\mathbf{~}} \\
\left(\mathbf{m g} / \mathbf{m}^{\mathbf{3}}\right)\end{array}$ & $\mathbf{X}(\mathbf{m})$ & $\mathbf{U} \mathbf{p r a v c u}$ & $\mathbf{q}(\mathbf{m g} / \mathbf{s})$ \\
\hline $\mathrm{W}$ & 0,11 & 3970,5 & $\mathrm{E}$ & 46150 \\
\hline $\mathrm{WNW}$ & 0,11 & 6103,4 & $\mathrm{ESE}$ & 112875 \\
\hline $\mathrm{NW}$ & 0,11 & 4976,1 & $\mathrm{SE}$ & 91000 \\
\hline
\end{tabular}

Na slici 3 je prikazana Zona uticaja od prašine sa flotacijskog jalovišta V.Krivelj.

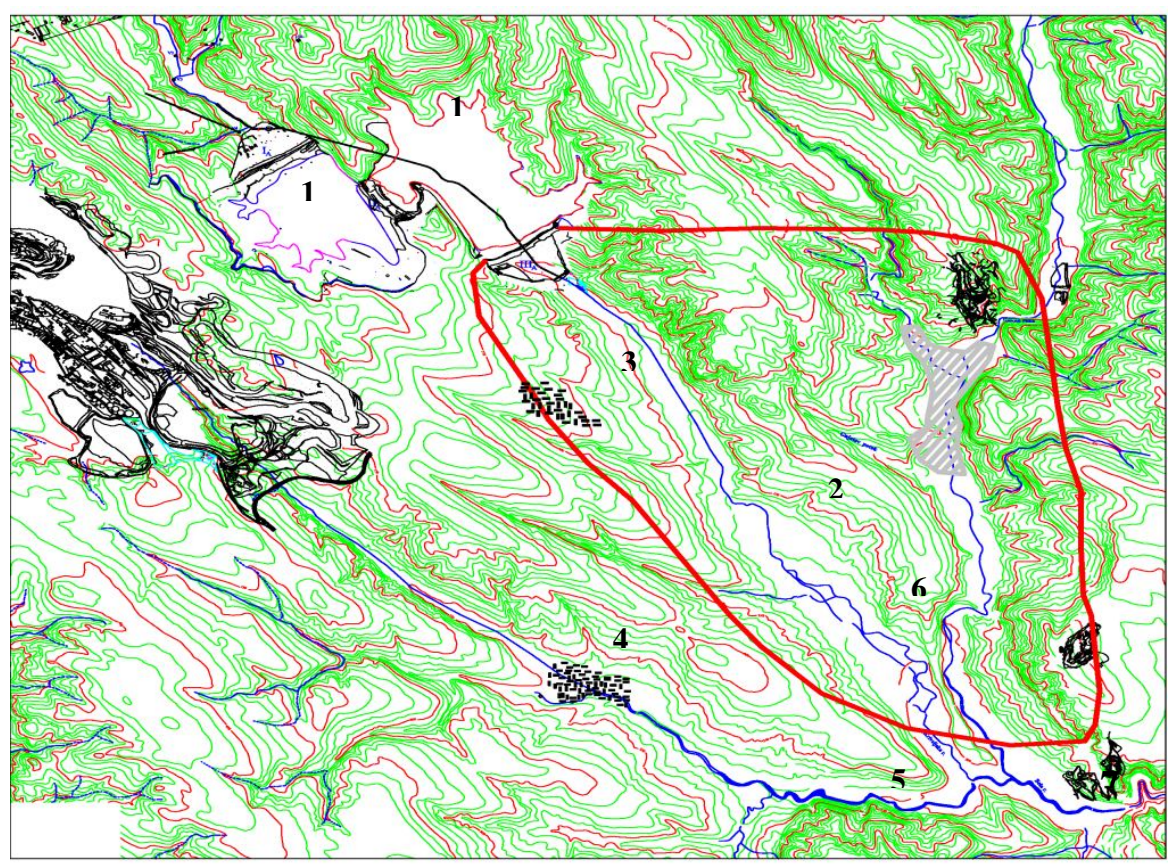

SI. 3. Zona uticaja od prašine sa flotacijskog jalovišta Veliki Krivelj

Legenda:1. FJ Veliki Krivelj, 2. zona uticaja prašine, 3. Ořtrelj, 4. Slatina, 5. Borska reka, 6. Kriveljska reka, 7. Bela reka

Površina prognozirane zone uticaja od prašine sa flotacijskog jalovišta Veliki Krivelj iznosi $16.077 .805 \mathrm{~m}^{2}$.

Opasnost po životnu sredinu predstavlja i kolektor ispod polja 2 FJ V. Krivelj, na kome se zbog neadekvatnih projektnih rešenja pri gradnji brane $3 \mathrm{~A}$ pojavile pukotine. Zidovi kolektora ispod brane $3 \mathrm{~A}$ su ojačani monolitnom oblogom od $40 \mathrm{~cm}$, I poprečni presek kolektora je sveden sa 3 na 
2,20 m. Opasnost od kolektora postoji na delu sa prelivnim organom I prema prognozi može doći do proboja flotacijske jalovine u Kriveljsku reku koja je pritoka Borske reke i zagađenja voda sve do Dunava.

Visina stuba isticanja fluidne mase prilikom mogućeg udesa iznosio bi $85,22 \mathrm{~m}$, a zapremina istekle fluidne mase iz odlagališta preko kolektora u Kriveljsku reku, Borsku Reku I Timoka iznosila bi oko 2.677.246,3 $\mathrm{m}^{3}$. Poprečni presek otvora oštećenja je poluprečnika na površini 104,4 $\mathrm{m}$, dok je poluprečnik otvora oštećenja prema prognozi $0,83 \mathrm{~m}$. Prosečna brzina isticanja fluidne mase prilikom mogućeg udesa iznosila bi $\mathrm{W}=29,37 \mathrm{~m} / \mathrm{s}$, dok bi prosečna količina isticanja bila $\mathrm{Q}=64,6 \mathrm{~m}^{3} / \mathrm{s}$. Ukupan poplavni talas Kriveljske reke iznosio bi $\mathrm{Q}_{\mathrm{u}}=47,67 \mathrm{~m}^{3} / \mathrm{s}$. Koncentracija zagađenja flotacijskom jalovinom $u$ Kriveljskoj reci na početku proboja iznosila bi $64,62 \%$.

\section{MERE ZAŠTITE}

U cilju zaštite životne sredine Bora od zagađenja sa flotacijskih jalovišta: Bor, RTH i V. Krivelj potrebno je da se uradi sledeće:

- da se rekultiviraju preostale površine na FJ Bor korišćenjem optimalne rekultivacije sa fazama agrotehničke, tehničke I bioločke rekultivacije,

- da se pri eksploataciji šljake, vrši konstatna vizuelna osmatranja, i vodi dnevnik o zapažanjima na terenu, $\mathrm{Na}$ ovaj način bi se vodilo računa $o$ stabilnosti brane 2 FJ RTH.

- da se drenažni system ispod brane $1 \mathrm{FJ}$ RTH stalno održava u funkciji I procedne vode pomoću pumpi vrate $\mathrm{u}$ taložno jezero jalovišta,

- da se vode taložnog jezera FJ RTH drže dalje od unutrašne kosine obodnog nasipa FJ RTH,

- da se po završetku procesa odlaganja jalovine završne površine FJ RTH rekultiviraju primenom optimalne rekultivacije,
- da se brana 3A FJ V. Krivelj rekultivira primenom optimalne rekultivacije,

- da se postojeći prelivni organ stavi van funkcije, a da se izgradi nov po terenu zapadno od brane 3A FJ V. Krivel,

- da se postojeći kolektor stavi van funkcije i po čvrstom terenu izgradi tunel koji koji će se nadovezati na postojeći tunel,

- i da se završne površine brane $1 \mathrm{~A}$ i brane 2A posle nadogradnje Polja 1 FJ Veliki Krivelj rekultiviraju

Nizvodno od ušća Kriveljske reke u Borsku reku treba izgraditi zaštitnu branu koja bi propustila vodu a zadržala flotacijski pesak I mulj, čime se plodne površine oko reke Timoka štite od zagađivanja.

\section{ZAKLJUČAK}

Treba pokloniti veliku pažnju zaštiti životne sredine Bora, grada u jugoistočnoj Srbiji, površina i vodenog sliva nizvodno od jalovišta (Timoka), jer su flotacijska jalovišta stalna opasnost na koja utiču prirodni faktori (katastrofe) i tehnički propusti u toku projektovanja i izgradnje istih. Iz tog razloga potrebno je odlagališni prostor iskoristiti potpuno kako se ne bi zauzele nove površine i zagadili novi tokovi reka. (4)

\section{REFERENCE}

[1] D. Kržanović, M. Mikić, M. Ljubojev, Analiza prostornog položaja rudničkih objekata rudnika Veliki Krivelj u odnosu na predloženu trasu tunela za izmeštanje Kriveljske reke, Rudarski radovi, 3/2011. str. 89-94.

[2] Kržanović D., Mikić M., Ljubojev M., Analiza uticaja razvoja rudnika Veliki Krivelj na izgradnju novih objekata za devijaciju Kriveljske reke, Rudarski radovi, 4/2011. god., str. 49-56. 
[3] Lekovski R., Bugarin M., Mikić M., Uzroci nastajanja udesa na flotacijskim jalovištima u Srbiji, Rudarski radovi, 3/2012, str. 99-106.

[4] Kržanović D., Mikić M., Ljubojev M., Auscultation and Zone Monitoring of Current Collector of the Krivelj River Below Flotation Tailing Dump "Veliki Krivelj“, $12^{\text {th }}$ Scientific Geoconference SGEM 2012, proceedings volume I, Geology Exploration and Mining. pp. 465-472.

[5] R. Lekovski, M. Mikić, M. Martinović, Zaštita životne sredine od uticaja odlagališta jalovine površinskog kopa kvarcnih peščara "DEO", Donja Bela Reka, Rudarski radovi, 1/2009. str. 107-114.
[6] R. Rajkovic, D. Kržanović, M. Mikić, Primena softverskog paketa Whittle za određivanje eksploatacionih rezervi ležišta bakra Severni revir - Majdanpek, Srbija, Rudarski radovi, 3/2012, str. 115-122.

[7] M. Ljubojev, D. Ignjatović, L. Đ. Ignjatović, V. Ljubojev, Pripreme za istraživanje trase tunela i snimanje terena, Rudarski radovi, 1/2011. str. 135-138.

[8] M. Ljubojev, D. Ignjatović, L. Đ. Ignjatović, Predlog poprečnog preseka tunela Kriveljske reke, Rudarski radovi, 1/2011, str. 73-78.

[9] D. Ignjatović, M. Ljubojev, L. Đ. Ignjatović, J. Petrović, Klasifikacija stenskog masiva pre izgradnje tunela (po Wickham-u i Bienawskom), Rudarski radovi, 1/2011, str. 65-68 